\title{
The Effect of Diabetes Self-Management Education, Based on The Health Belief Model, on the Psychosocial Outcome of Type 2 Diabetic Patients in Indonesia
}

\author{
Rondhianto $^{1}$, Kusnanto ${ }^{2}$, Soenarnatalina Melaniani ${ }^{3}$ \\ ${ }^{I}$ Doctoral Program of Public Health, Universitas Airlangga, Faculty of Nursing, Universitas Jember; \\ ${ }^{2}$ Faculty of Nursing; ${ }^{3}$ Department Biostatistics and Population Study, Faculty of Public Health, \\ Universitas Airlangga
}

\begin{abstract}
Lack of knowledge on disease management may distress type 2 diabetic patients, which could negatively affect their quality of life. The health belief model has been widely used to improve the patient's knowledge, skill, and abilities in relation to self-care. The study aimed to examine the effect of diabetes self-management education, based on the Health Belief Model (HBM), on the psychosocial outcome (self-efficacy, self-care behaviour, distress, and quality of life), and glycemic control (measured by their blood glucose level). A randomised control trial was employed, using a pre-test-post-test design. Our study recruited 120 type 2 diabetic patients who were equally assigned to the intervention group $(n=60)$ and the control group $(n=60)$. The data was analysed using an independent $t$ test with a significance level of 0.05 . After the intervention, the intervention group and control group showed significantly different scores in self-efficacy, self-care behaviour, diabetes distress, quality of life, and blood glucose level. Diabetes self-management education based on the HBM had a significant effect on the phycosocial outcome of patients with type 2 diabetes.
\end{abstract}

Keywords: health education, health belief model, type 2 diabetes, psycosocial outcome, glycemic control.

\section{INTRODUCTION}

Diabetes Mellitus (DM) is a major chronic disease in the world which can cause heart disease, blindness, renal failure and lower extremity amputations. ${ }^{1,2}$ Globally, the number of people living with type $2 \mathrm{DM}$ was approximately 424.9 million people in $2017 .{ }^{2}$ Type 2 diabetes affected almost $6.7 \%$ of the Indonesia population, approximately 10.3 million people, in $2017 .^{2}$ Worldwide, Indonesia is ranked $6^{\text {th }}$ among countries with a high percentage of the population with type 2 DM, after China, India, the United States, Brazil and Mexico. ${ }^{2}$ Diabetes type 2 is the third leading cause of death in Indonesia after stroke $(21.1 \%)$ and coronary heart disease $(12.9 \%){ }^{3}$

\section{Corresponding Author:}

Rondhianto

Doctoral Program of Public Health, Faculty of Public Health, Universitas Airlangga

Faculty of Nursing, Universitas Jember

Email: rondhianto-2017@fkm.unair.ac.id
Living with diabetes can be difficult for patients and their families. Diabetic patients can show negative psychological responses, including feeling guilty and hopeless, losing confidence, having a low self-image, and becoming anxious and angry. ${ }^{4,5}$ Diabetes distress is an additional burden for patients and their families, as a result of the cost incurred due to long-term care and treatments. Appropriate treatment is required to prevent disability, poor productivity, low quality of life and increased mortality. ${ }^{6}$ Patients and their families should acquire the knowledge, skills and self-efficacy related to the proper self-management of DM for successful treatment. $^{7,8}$ The Health Belief Model (HBM) is a constructed model that has been widely used to predict adherence to self-care behaviour. ${ }^{9}$ It consists of five core components, including perceived severity, perceived susceptibility, cues to action, perceived benefits and perceived barriers. Perceived severity relates to beliefs on the severity level of the disease and the consequences relevant to the illness. Perceived susceptibility represents to what extent the person perceives their risk of having the illness. Cues to action reflects the internal or external 
indications such as physical symptoms (internal) and medication reminders (external). Perceived benefits involves the individual's perception toward the advantages and accessibility of the actions that they are to take. Perceived barriers includes the negative consequences from the actions taken. ${ }^{9}$ The study aimed to examine the effect of diabetes self-management education, based on HBM, on psychosocial outcome (self-efficacy, self-care behaviour, distress and quality of life), and glycemic control.

\section{METHOD}

The study employed a randomised control trial with a pre-test- post-test design. The study population was made up of 382 patients with type $2 \mathrm{DM}$ attending the Patrang community health center $(\mathrm{CHC})$ in Jember district, East Java in Indonesia. The inclusion criteria was that the patients had been diagnosed with type $2 \mathrm{DM}$ within the last six months, who showed compos mentis mindfulness and were generally in good condition. Their age should have been between 40 and 65 years old, they lived within the Patrang $\mathrm{CHC}$ service area, and expressed a willingness to participate in the study. Patients with a cognitive impairment (dementia and active psychosis) were excluded. 260 patients met the inclusion and exclusion criteria.

Using the $95 \%$ confidence interval $(\alpha=0.05)$ and a statistical power of $80 \%(\beta=0.20)$, the sample size for the intervention group and control group was 55 subjects each. To anticipate the participants dropping out, an additional $10 \%$ was determined, resulting in 60 subjects recruited for each group. Simple random sampling was applied in order to select the study participants.

The intervention group received a six-week educational program using the HBM approach over six sessions. The control group received their usual daily care. Every educational session lasted for approximately 120 minutes. The intervention group received knowledge about diabetes and self-management activities based on the four main sources of self-efficacy including performance accomplishment, vicarious experience, verbal persuasion, and physiological and emotional arousal. The six intervention sessions were divided into two home visit sessions (sessions 1 and 6) and four group sessions (sessions 2-5). The educational program was prepared based on the national standard for diabetes self-management education and support, and the management and prevention of type $2 \mathrm{DM}$ from the Indonesian Endocrinology Association (PERKENI). Additional information was obtained from the American Diabetes Association (ADA). The pre-test was conducted before the intervention started, while the post-test was conducted three months after the intervention.

The pre-test and post-test questionnaires used four scales to measure the psychosicial outcome, including the diabetes management self-efficacy scale (DMSES), the diabetes distress scale (DDS), the summary of diabetes self-care activities (SDSCA), and the diabetes quality of life scale (DQOL), in addition to the glycemic control test tool. The DMSES questionnaire used was a modified version by Shi, Ostwald, \& Wang (2010) from the van der Bijl instrument. ${ }^{10}$ The DMSES questionnaire consisted of 20 items with a Likert scale of 1-5. The results of the validity test showed an r-value of 0.658 , and reliability test of $\alpha=0.975$. The DDS questionnaire of 17 items was adopted from the instrument developed by Polonsky, et al. (2005). ${ }^{11}$ The results of the DDS validity test showed an $\mathrm{r}$-value that was larger than 0.537 , with a reliability test of $\alpha=0.874$. The SDSCA questionnaire consisted of 12 items with a scoring system of $0-7$, using the Wu modified version (2009) from the Toobert SDSCA instrument. ${ }^{12}$ The SDCA validity test result was $r=0.632$, with the reliability test being $\alpha=0.923$. The DQOL questionnaire had 30 items with multiple selection available, scored using the Likert scale. The DQOL result of the validity was $r>0.36$, and the reliability test $\alpha=0.956$. The data analysis used an independent t-test to examine the group differences with a significance $p$-value of $\alpha \leq 0.05$.

\section{RESULTS}

Table 1 shows the mean of patient age was 57.60 years. Most of the patients were female $(65 \%)$, employed $(65 \%)$, and had an education level of junior high school $(41.67 \%)$. The average duration of illness among the patients was 45.07 months. The patient characteristics showed no significant difference between the intervention group and the control group. Table 1 displays the baseline score of self-efficacy, self-care behaviour, diabetes distress, quality of life and blood glucose level. The mean scores for self-efficacy, selfcare behaviour, diabetes distress, and quality of life were $41.63,15.13,39.00$, and 65.77 respectively, with no significant difference between the intervention group and the control group. Likewise, the average blood glucose level was $207.62 \mathrm{mg} / \mathrm{dl}$, and no significant difference was observed between the intervention group and the control group. 
Table 1: Baseline characteristics of all patients $(n=120)$ in the intervention group and the control group (n=60/group)

\begin{tabular}{|c|c|c|c|c|}
\hline Variable & $\begin{array}{l}\text { All patients }(\mathrm{n}, \%) \\
\text { or mean } \pm \text { SD }\end{array}$ & $\begin{array}{c}\text { Intervention group } \\
(\mathrm{n}, \%) \text { or mean } \pm \mathrm{SD}\end{array}$ & $\begin{array}{l}\text { Control group (n, } \\
\%) \text { or mean } \pm \text { SD }\end{array}$ & P-value \\
\hline Age (years) & $57.60 \pm 6.25$ & $57.50 \pm 6.83$ & $57.70 \pm 5.65$ & 0.862 \\
\hline \multicolumn{5}{|l|}{ Gender } \\
\hline Female & $76(63.33 \%)$ & $42(70 \%)$ & $34(56.67 \%)$ & \multirow{2}{*}{0.132} \\
\hline Male & $44(36.67 \%)$ & $18(30 \%)$ & $26(43.33 \%)$ & \\
\hline \multicolumn{5}{|l|}{ Employment } \\
\hline Employed & $78(65 \%)$ & $38(63.33 \%)$ & $40(66.67 \%)$ & \multirow{2}{*}{0.718} \\
\hline Unemployed/retired/house- wife & $42(35 \%)$ & $22(36.67 \%)$ & $20(33.33 \%)$ & \\
\hline Duration of illness & $45.07 \pm 33.05$ & $45.33 \pm 37.45$ & $44.80 \pm 28.28$ & 0.930 \\
\hline \multicolumn{5}{|l|}{ Level of education } \\
\hline Elementary school & $39(32.5 \%)$ & $18(30 \%)$ & $21(35 \%)$ & \multirow{4}{*}{0.769} \\
\hline Junior high school & $50(41.67 \%)$ & $24(40 \%)$ & $26(43.33 \%)$ & \\
\hline Senior high school & $23(19.17 \%)$ & $12(20 \%)$ & $11(18.33 \%)$ & \\
\hline Higher education & $8(6.67 \%)$ & $6(10 \%)$ & $2(3.33 \%)$ & \\
\hline Self-efficacy score & $41.63 \pm 8.75$ & $41.83 \pm 9.67$ & $41.43 \pm 7.80$ & 0.803 \\
\hline Self-care behaviour score & $15.13 \pm 4.86$ & $14.93 \pm 4.64$ & $15.33 \pm 5.10$ & 0.654 \\
\hline Diabetes distress score & $39.00 \pm 6.11$ & $39.33 \pm 6.87$ & $38.67 \pm 5.28$ & 0.552 \\
\hline Quality of life score & $65.77 \pm 15.37$ & $66.03 \pm 17.09$ & $65.50 \pm 13.57$ & 0.850 \\
\hline Blood glucose level (mg/dl) & $207.62 \pm 63.69$ & $207.62 \pm 63.69$ & $197.37 \pm 65.91$ & 0.078 \\
\hline
\end{tabular}

Table 2 shows that both groups had increased scores for self-efficacy, self-care, and quality of life from the baseline. The diabetes distress score and blood glucose level were reduced in both groups after the intervention. The post-test results show a statistically significant difference in each score of the psychosocial outcome between the intervention group and the control group. A more significant improvement in psychosocial outcome was experienced by the intervention group than the control group, indicating the positive effect of diabetes self-management education using the HBM approach.

Table 2: Comparison of the pre- and post-intervention variables of each group and the results of the independent t-test after the intervention

\begin{tabular}{|c|c|c|c|c|c|c|c|c|}
\hline \multirow{2}{*}{ Variable* } & Intervention group (n= 60) & \multicolumn{2}{|c|}{ Control group (n= 60) } & F & p-value & t & p-value \\
\cline { 2 - 9 } & Pre & Post & Pre & Post & & 0.001 & 3.434 & 0.001 \\
\hline $\begin{array}{c}\text { Self-efficacy } \\
\text { score }\end{array}$ & $41.83 \pm 9.67$ & $61.87 \pm 6.84$ & $41.43 \pm 7.80$ & $56.10 \pm 11.06$ & 11.618 & 0.001 & 0.044 \\
\hline $\begin{array}{c}\text { Self-care } \\
\text { behaviour } \\
\text { score }\end{array}$ & $14.93 \pm 4.64$ & $23.90 \pm 6.49$ & $15.33 \pm 5.10$ & $21.83 \pm 4.43$ & 13.893 & 0.001 & 2.039 & 0.001 \\
\hline $\begin{array}{c}\text { Diabetes } \\
\text { distress score }\end{array}$ & $39.33 \pm 6.87$ & $28.23 \pm 3.79$ & $38.67 \pm 5.28$ & $35.27 \pm 5.76$ & 22.865 & 0.001 & -7.889 & 0.001 \\
\hline $\begin{array}{c}\text { Quality of life } \\
\text { score }\end{array}$ & $66.03 \pm 17.09$ & $92.33 \pm 11.17$ & $65.50 \pm 13.57$ & $77.73 \pm 15.67$ & 6.775 & 0.010 & 5.878 & 0.001 \\
\hline $\begin{array}{c}\text { Blood glucose } \\
\text { level (mg/dl) }\end{array}$ & $207.62 \pm 63.69$ & $118.25 \pm 23.50$ & $197.37 \pm 65.91$ & $187.37 \pm 52.49$ & 19.625 & 0.001 & -9.310 & 0.001 \\
\hline
\end{tabular}

*data expressed as mean \pm standard deviation 


\section{DISCUSSION}

Characteristics of the study participants: The average age of the diabetic patients was 57.6 years old, confirming the previous study stating that insulin retention tends to increase by the age of 45 years old or older. ${ }^{4}$ Individuals older than 45 years old have an increased risk of developing type 2 diabetes by almost 15 times compared to younger individuals. ${ }^{3}$ Most of the patients with type 2 diabetes in this study were female, again confirming the results of previous studies. ${ }^{7,13}$ Elderly women may have a higher LDL cholesterol and trigliserida level than men, which affects the decreasing level of their insulin sensitivity. ${ }^{14}$ The average duration of illness among the diabetic patients in the present study was 45.07 months, or almost four years. The risk of macrovascular complication from diabetes increased in the fifth year since the diabetes was first diagnosed. ${ }^{15}$

In our study, most of the participants in both groups had completed junior high school and were employed. Level of education may influence the individual's acceptance of information and their capacity to manage stressors. ${ }^{16,17}$ Being employed could increase the individual's self-confidence in relation to problem solving, as having a source of income which enable them to access information, appropriate care and better treatment. ${ }^{18,19}$

Self-efficacy before and after the intervention: The results of the data analysis showed that there was a significant difference in the self-efficacy between the groups after the intervention. Perceived self-efficacy affects the way that someone understands, feels, senses, drives their self-motivation, and takes action, which can generate effects through cognitive, motivational, affective and selection processes. ${ }^{20}$ Improving the patient's perception of their vulnerability and the disease severity during the health education intervention could help patients to manage the disease, which increases their self-efficacy. ${ }^{21,22}$

Self-care behaviour before and after the intervention: The results showed that there were significant differences related to self-care behaviour between the intervention group and the control group. The acquisition of knowledge about the disease and care management of the disease is crucial in helping diabetic patients perform the proper self-care behaviour. ${ }^{8}$ Self-care depends on the patient's ability to make decisions and daily assessments in order to implement comprehensive diabetes management. ${ }^{12}$ Diabetes patients with a good self-care ability can control their blood sugar levels by changing to a healthier lifestyle. ${ }^{23}$

\section{Diabetes Distress before and after intervention:}

The intervention group experienced a more significant decrease in their diabetes distress score than the control group after the educational intervention. Having proper health education can help them to gain self-control so then the patient can maintain an ideal health condition and reduce stress. ${ }^{19}$ Acquiring coping strategies to reduce stress could encourage diabetic patients to seek social support from their family, friends, neighbours and co-workers. ${ }^{24}$ Having cognitive skills would increase the patient's understanding and acceptance of their condition, so as to reduce the level of stress. ${ }^{19}$

Quality of life before and after the intervention: An essential key to the quality of life assessment was the satisfaction of self-care. Health workers have an important role in providing proper health education to patients and their families in promoting the self-care of diabetes with complications, in order to achieve an optimal quality of life. ${ }^{7,25}$ The ability to perform self-care and knowing how to reduce the risk of complications could improve quality of life. ${ }^{1}$

Glycemic control: The intervention group had a more significantly reduced level of blood sugar than the control group after the HBM educational intervention. Knowledge about diabetes helped the patient to control the disease and to reduce the risk of disability. ${ }^{15}, 22$ The diabetes self-management education (DSME) significantly reduced the patient's fasting blood glucose level, improved their diabetes knowledge, selfmanagement skill and self-efficacy. ${ }^{26}$

\section{CONCLUSION}

This study has highlighted the importance of health education in improving the patient's psychosocial outcome. This educational intervention, along with the HBM approach, has significantly improved selfefficacy, self-care behaviour and quality of life, as well as reducing the level of diabetes distress and their blood glucose level. The diabetes self-management education based on the Health Belief Model is recommended to be used as a health education intervention for patients with type 2 diabetes. 
Ethical Clearance: Ethical approval was granted by the School of Public Health in Airlangga University, Surabaya.

Source of Funding: Self funding.

\section{Conflict of Interest: None.}

\section{REFERENCES}

1. American Diabetes Association [ADA]. Standards of Medical Care in Diabetes-2018. Diabetes Care. 2018;37.

2. International Diabetes Federation [IDF]. Diabetes Atlas 2017 Brussel: International Diabetes Federation; 2017 [Available from: https://www. idf.org/e-library/epidemiology-research/diabetesatlas.html.

3. MoH. Situasi dan analisis diabetes. Jakarta: Kementerian Kesehatan RI; 2013.

4. Smeltzer SC, Bare BG, Hinkle JL, Cheever KH. Brunner and Suddarth's textbook of medical surgical nursing. 12 ed. Philadelpia: Lippincott Williams \& Wilkins; 2013.

5. Penckofer S, Ferrans CE, Velsor-Friedrich B, Savoy S. The psychological impact of living with diabetes women's day-to-day experiences. The Diabetes Educator. 2007;33(4):680-90.

6. MoH. Menkes: Mari Kita Cegah Diabetes dengan CERDIK (Health Minister: Let us prevent diabetes by CERDIK) 2016 [Available from: http://www. depkes.go.id/article/print/16040700002/menkesmari-kita-cegah-diabetes-dengan-cerdik.html

7. Shrivastava SR, Shrivastava PS, Ramasamy J. Role of self-care in management of diabetes mellitus. Journal of Diabetes \& Metabolic Disorders. 2013;12(1):14.

8. Atak N, Gurkan T, Kose K. The effect of education on knowledge, self management behaviours and self efficacy of patients with type 2 diabetes. Australian journal of advanced nursing. 2008;26(2):66-74.

9. Jones CJ, Smith H, Llewellyn C. Evaluating the effectiveness of health belief model interventions in improving adherence: a systematic review. Health Psychology Review. 2014;8(3):253-69.
10. Shi Q, Ostwald SK, Wang S. Improving glycaemic control self-efficacy and glycaemic control behaviour in Chinese patients with Type 2 diabetes mellitus: randomised controlled trial. Journal of clinical nursing. 2010;19(3-4):398-404.

11. Polonsky WH, Fisher L, Earles J, Dudl RJ, Lees $\mathrm{J}$, Mullan J, et al. Assessing psychosocial distress in diabetes: development of the diabetes distress scale. Diabetes care. 2005;28(3):626-31.

12. Wu SF. Effectiveness of self-management for persons with type 2 diabetes following the implementation of a self-efficacy enhancing intervention program in Taiwan: Queensland University of Technology; 2007.

13. Miller TA, DiMatteo MR. Importance of family/ social support and impact on adherence to diabetic therapy. Diabetes, metabolic syndrome and obesity: targets and therapy. 2013;6:421.

14. DeFronzo RA, Ferrannini E, Alberti KGMM, Zimmet P, Alberti G. International Textbook of Diabetes Mellitus, 2 Volume Set: John Wiley \& Sons; 2015.

15. Waspadji S. Diabetes Melitus, Penyulit Kronik, dan Pencegahannya. Dalam: Penatalaksanaan Diabetes Melitus Terpadu Jakarta: Balai Penerbit Fakultas Kedokteran Universitas Indonesia. 2007.

16. Notoatmodjo S. Promosi kesehatan dan ilmu perilaku. Jakarta: Rineka Cipta. 2007;20.

17. Khan TM, Sulaiman S, Hassali MA. The causes of depression? A survey among Malaysians about perception for causes of depression. Asian Journal of Pharmaceutical and Clinical Research. 2008;2(2).

18. Lau-Walker M. Importance of illness beliefs and self-efficacy for patients with coronary heart disease. Journal of Advanced Nursing. 2007;60(2):187-98.

19. Powers MA, Bardsley J, Cypress M, Duker P, Funnell MM, Hess Fischl A, et al. Diabetes Selfmanagement Education and Support in Type 2 Diabetes: A Joint Position Statement of the American Diabetes Association, the American Association of Diabetes Educators, and the Academy of Nutrition and Dietetics. Diabetes Care. 2015;38(7):1372-82. 
20. Bandura A. Perceived self-efficacy in cognitive development and functioning. Educational psychologist. 1993;28(2):117-48.

21. Edberg M. Buku Ajar Kesehatan Masyarakat Teori Sosial dan Perilaku. Alih bahasa: Anwar, dkk, Jakarta: EGC. 2010.

22. Zulman DM, Rosland A-M, Choi H, Langa KM, Heisler M. The influence of diabetes psychosocial attributes and self-management practices on change in diabetes status. Patient education and counseling. 2012;87(1):74-80.

23. Gao J, Wang J, Zheng P, Haardörfer R, Kegler MC, Zhu Y, et al. Effects of self-care, selfefficacy, social support on glycemic control in adults with type 2 diabetes. BMC family practice. 2013;14(1):66.

24. Wade C, Travis C. Psychology. 9 ed. Upper Saddle River, NJ: Pearson Education, Inc; 2007.

25. PERKENI. Konsensus pengelolaan dan pencegahan diabetes melitus tipe 2 di Indonesia 2015. Jakarta: PB. PERKENI; 2015.

26. Steinsbekk A, Rygg L, Lisulo M, Rise MB, Fretheim A. Group based diabetes selfmanagement education compared to routine treatment for people with type 2 diabetes mellitus. A systematic review with meta-analysis. BMC Health Services Research. 2012;12(1):213. 